\title{
Effect of hail net on the water potential of an apple orchard
}

\author{
Andrea Szabó - Kinga Kubicza - János Tamás - Attila Nagy \\ University of Debrecen, Faculty of Agricultural and Food Sciences and Environmental Management, Institute of Water and Environmental \\ Management \\ szabo.andrea@agr.unideb.hu
}

\begin{abstract}
SUMMARY
Apple production has seen a decline in yields in recent years, primarily due to ecological factors such as drought, water stress, water scarcity, uneven rainfall distribution, frost damage and hail damage. Ecological factors that are harmful to the plant can be eliminated by human intervention, irrigation or the use of hail net. In our study, we investigated the positive effects of hail net on the development of plant water potential as the vegetation progressed, in non-irrigation area with temperature and humidity. Water potential values were determined using a field osmometer. Confirmed the positive effect of the ice protection net in the apple orchard of Early Gold and Golden Reinders. Our results were supported by statistical analyzes our results.
\end{abstract}

Keywords: apple, water potential, hail net

\section{INTRODUCTION}

Apples are grown in the largest areas in the Northern Great Plain in Hungary with an average apple production of 550-600 thousand tonnes, which is the $5^{\text {th }}$ largest in Europe (Gonda and Csihon, 2018). Areas where all the conditions are favorable and intensive plantations with a high plant number provide 40-45 $\mathrm{t} \mathrm{ha}^{-1}$ yield. Due to the continental climate, frost damage is frequent in autumn, spring and winter, and the occurrence of drought is significant in summer. Domestic plantations are able to produce an average yield of up to 30-40 $\mathrm{t} \mathrm{ha}^{-1}$ during these effects, (Gonda and Apáti, 2011). Apples have an average annual heat demand of $10-11^{\circ} \mathrm{C}$ according to their agro-ecological needs and prefer acidic soils to $\mathrm{pH}$ 5.8-7.0 (Kállay, 2014). Apples are a water-demanding fruit species, requiring about $750-800 \mathrm{~mm}$ of precipitation/year. It is highest water demand is from the beginning of June to the end of August. The quality of the fruit and the safety of the crop can be endangered by intensive plantations even if the critical water supply lasts only a few days during this period (Petesné, 2008). The use of hail net an intensive plantation supplement can be very useful and economical (Szabó, 2016), since hail can cause a serious problem in apple cultivation, where even a small amount of ice can degrade the apple so that it can only be sold for juice production (Kadosa, 2010). Use of the hail net have some positive effects on a given stock, one of the most important of which is temperature, where it plays a role in reducing extreme fluctuations. Another advantage is the possibility of water-saving production since the wind speed decreases, so the amount of water evaporated by the trees will be reduced by 30-40\% (Lakatos et al., 2011). The plant water potential is the chemical potential of a system or part of the system water, expressed in terms of pressure, relative to the chemical potential of pure water. The value of water potential is highest in soil and lowest in air, and gives a temporary value from soil to air in the plant under normal conditions (Ördög and Molnár, 2011). The value of water potential, due to environmental reasons, is a key variable in the functioning of plant life. The two basic factors that determine the value of water potential are the concentration of solutions and the value of hydrostatic pressure. The gradient of water pressure in xylem as well as negative pressure can be detected. Scholander (1965) constructed a thick-walled pressure chamber container in which the leaf or fold was sealed and pressurized into an opening, and the leaves were placed in a chamber to measure the pressure present in the leaf or fold. In a closed container, the pressure was increased until the plant sap appeared on the cut surface (Boyer, 1967; Teszlák, 2008; Bratek et al., 2013). The pressure that water exerts on the cut surface indicates how much stress the leaf is experiencing in the water supply. High pressure means high water and high tension which vary within species and breeds. The water potential value in plants and its measurement has recently received considerable attention as water potential indicates the need for water within the plant. High water potential values affect the physiological processes of the plant, including slowing down or total stopping of photosynthesis, which reduces plant growth and ultimately causes plant death. This value can serve as a guide for improving growth and yield. Its unit is expressed in megapascal (Mpa) (McDowell et al., 2008; Klein, 2014; Steppe, 2018). Since the effect of hail net on the water potential of apple canopy thus on the water balance of apple orchards is not well studied, we aimed to analyse the effect of the hail net on the water supply and balance of apple orchards based on measuring water potential of apple canopy and microclimate data.

\section{MATERIALS AND METHODS}

The research was carried out in an intensive apple orchard with a drip irrigation system at the Horticultural Experimental Plant of Pallag, University of Debrecen. The orchard is located on sandy soils with extreme water content and stress caused by water scarcity is high risk on this area (Nagy, 2014). Our 
tested varieties were Early Gold and Golden Reinders. There are 100 trees in each row, the first 50 are protected by an hail net and the second 50 are not protected by an hail net. Sampling was performed twice weekly, between 9 and 10 am, 15 July 2019 to 29 August 2019 for 6 weeks, when we measured the temperature, humidity, and water potential values (Table 1). We were taken the leaf samples from shaded portions of marked trees of homogeneous stands at identical heights. A suitable device for measuring water potential is the Pump-Up Chamber (PMS Instrument Company), in which the pressure chamber presses the leaf or the drive. Water potential values were measured at the time of sampling of 10 specimens of each species protected with hail net and 10 samples of individuals without hail net. Soil samples were not collected to detect the soil moisture content, because of the homogeneity of both soil physical and chemical characteristics of the investigated 0.5 ha orchard (Nagy et al., 2011). Furthermore, the utilized water for irrigation were also homogenous.

At the beginning of the measurement leaf or shoot specimens are bladed from the test plant 10 minutes after being placed in the sampling bag. After removing the Pump-Up Chamber's chamber pins and the chamber cover, the stem is inserted into the hole in the center of the lid, and the compression opening is rotated clockwise to tighten the seal around the pattern. We should be continuously monitored during pumping the samples. Each pumping takes approx increase the pressure by $1 / 2$ bar when the plant sap appears on the sample, stop pumping and read off the pressure. A pressure relief valve is used to completely relieve the pressure and the following sample can be measured after removal of the taps and vent cover (Fulton et al., 2014) (Figure 1).

Table 1

Sampling dates

\begin{tabular}{cc}
\hline Early Gold & Golden Reinders \\
\hline 1: 17 July & $1: 15$ July \\
2: 23 July & $2: 22$ July \\
3: 31 July & $3: 30$ July \\
4: 8 August & $4: 6$ August \\
5: 13August & $5: 12$ August \\
6: 29 August & $6: 28$ August
\end{tabular}

Measurement of Plant Water Potential with Pump-Up Chamber (PMS Instrument Company)

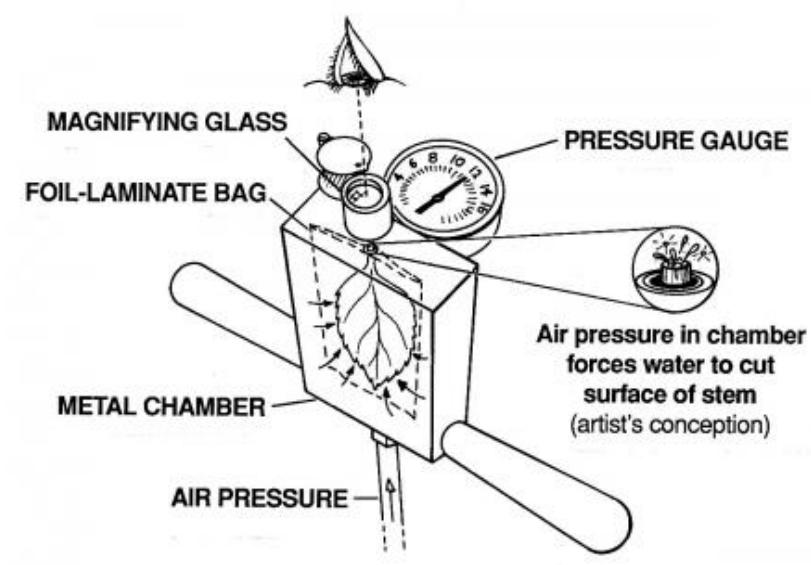

Source: PMS instruments Company

The obtained water potential results were performed using $\mathrm{R}$ software in the $\mathrm{R}$ studio user environment using the agricolae package (Mendiburu, 2019) to determine significant differences between the results. Statistical analyzes included mean, standard deviation, minimum and maximum values using the Shapiro-Wilk test and the Duncan-test.

\section{RESULTS AND DISCUSSION}

\section{Effect of hail net on the microclimate}

Microclimate data were collected during the studies, the measured parameters were the temperature and humidity, on which the hail net can have a positive effect, in correspondence with Lakatos et al. (2011) study. Early Gold shows the positive effect of hail nets on these parameters. Humidity is nearly the same or higher in the area below the hail net. Taking into account the temperature, the positive effect of the net can be seen, since the hail net reduces the high temperatures. Based on our values it can be observed that the temperature difference is $1-2^{\circ} \mathrm{C}$ in each of our measurements. Early Gold 6 measures the time of the morning with the consistently high temperatures already in the morning. Low humidity was obtained during prolonged high temperature and low precipitation (Figure 2). 
Figure 2: Early Gold temperature and humidity values

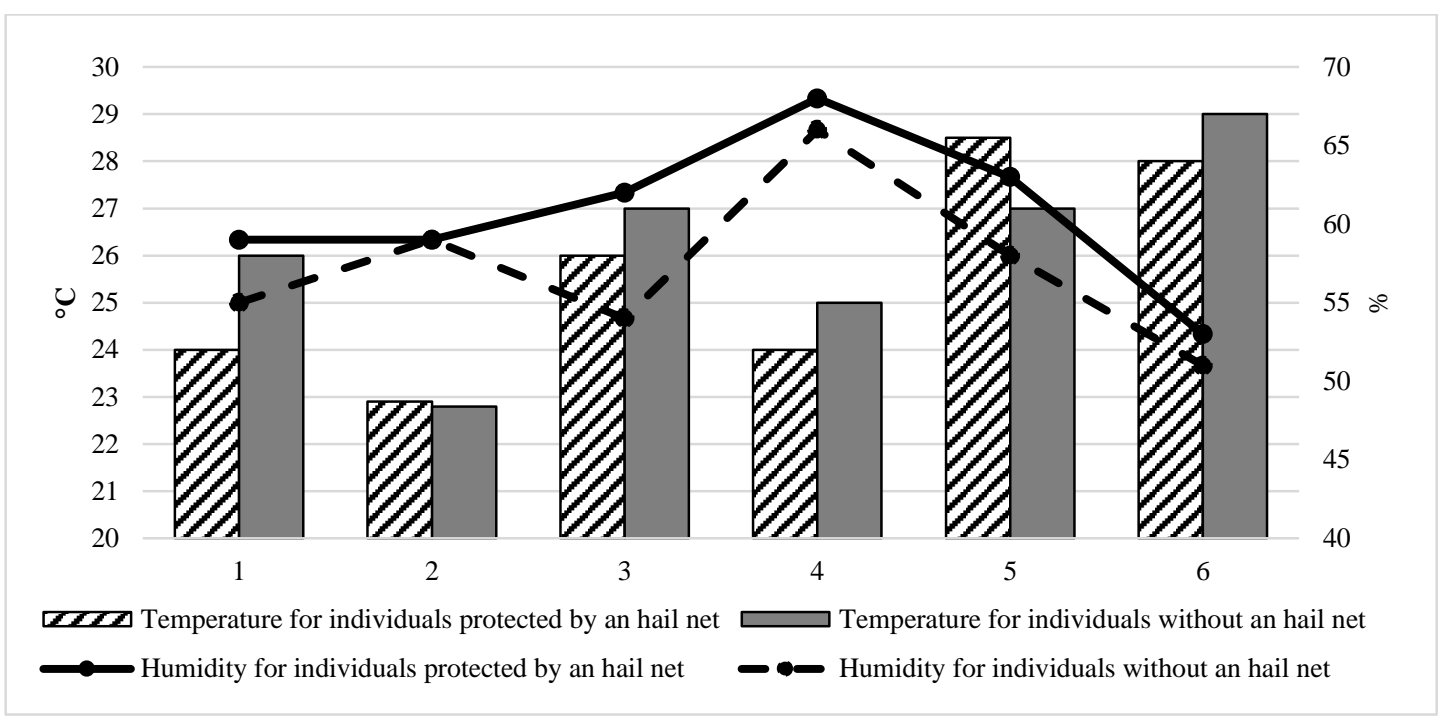

Based on the results the positive effect of the hail net on the Golden Reinders was detected (Figure 3). The humidity increasing effect of the hail net is positive for almost all measurements and lowers the temperature compared to the non-mesh area. The low humidity was measured due to the absence of rainfall and high temperatures, with peak temperatures reaching $29^{\circ} \mathrm{C}$ in the morning as Early Gold.

Figure 3: Golden Reinders temperature and humidity values

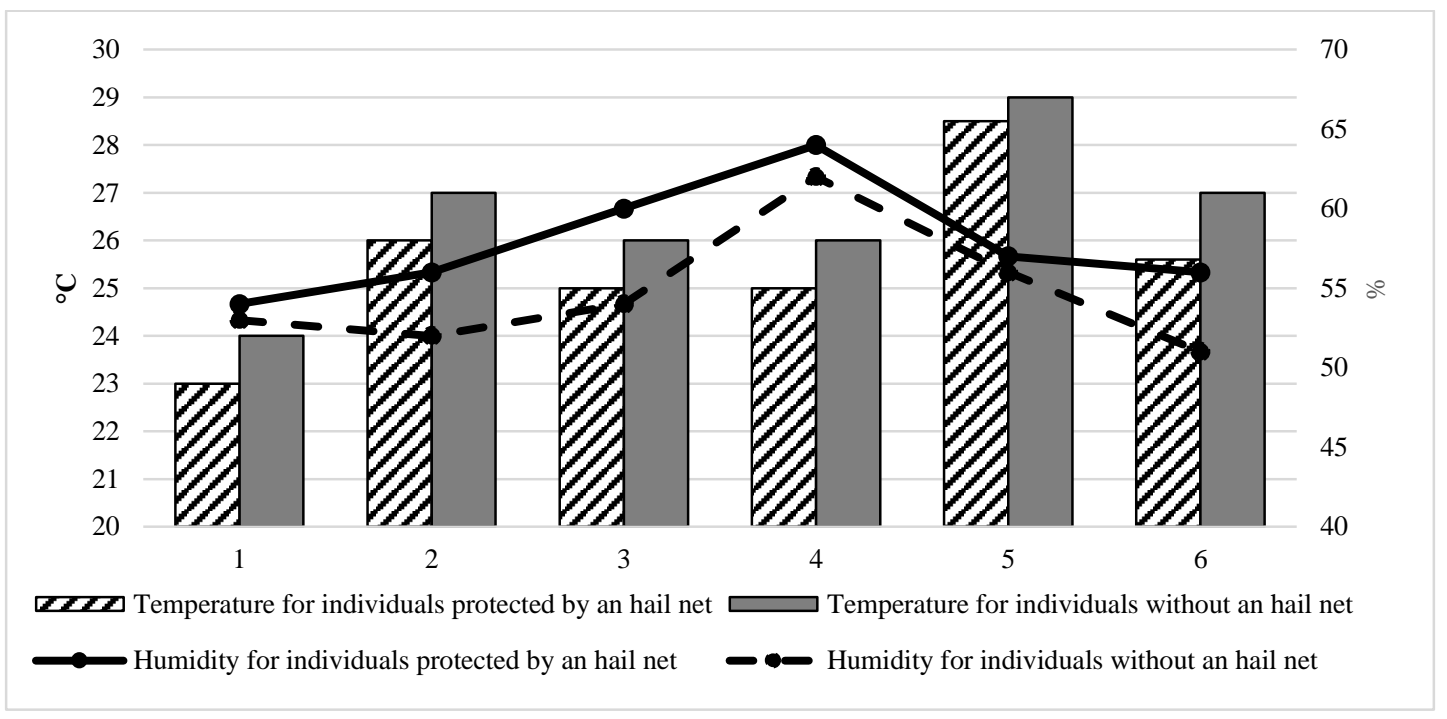

Effect of hail net on the water potential of Early Gold

The water content of plants is subject to negative pressure, it is scientifically stated that the water potential of plants (Stem water potential - SWP) is given as negative values (Fulton et al., 2014). The mean value of hail net individuals was -8 bar, while the average value of without hail net individuals was -11 bar, the difference was not significant ( $\mathrm{p}=0.837)$. In the case of Early Gold the individuals protected by the hail net had higher water potential values at each measurement point, which indicates the better water balance of the individuals, thus the effect of the hail net on the plant water balance (Figure 4). 
Figure 4: Early Gold water potential values

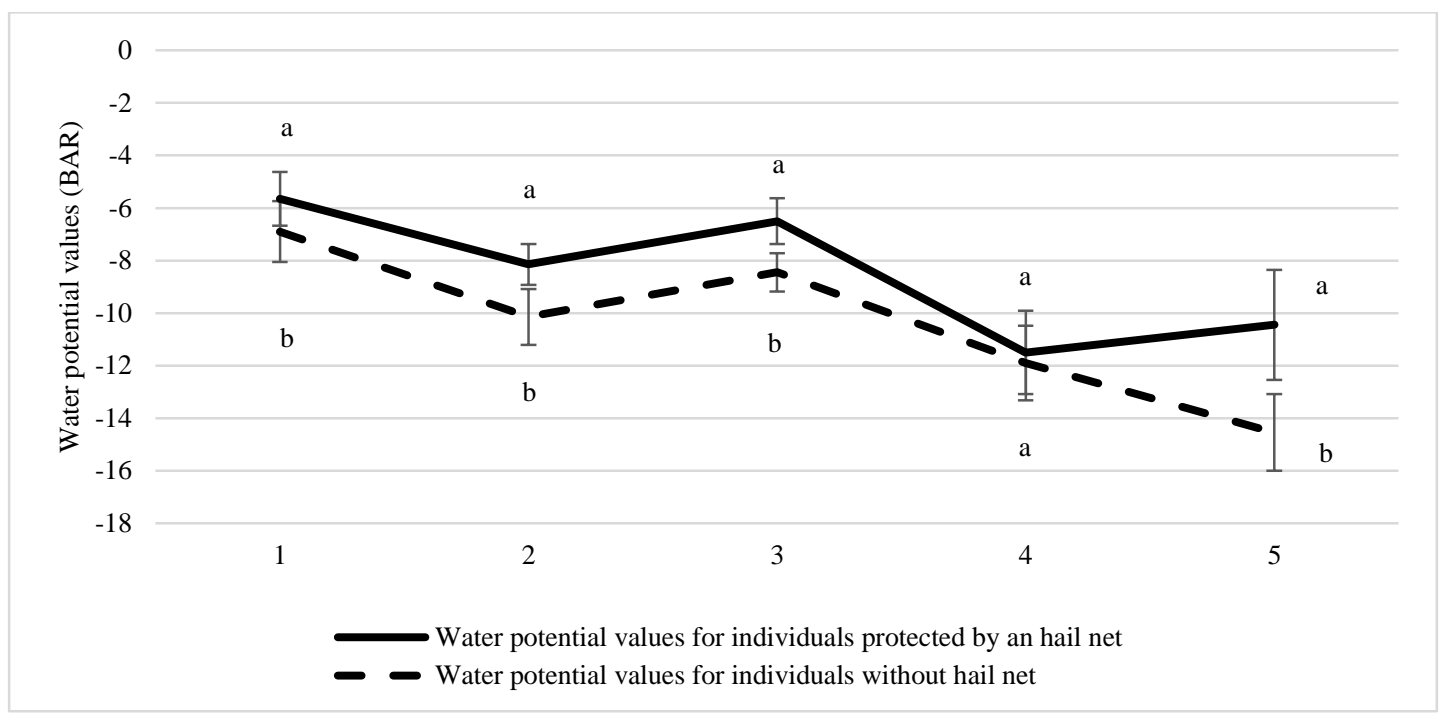

There is no statistical difference between populations marked with the same letter as index character ( $>0.05)$

Effect of hail net on the water potential of Golden Reinders

Taking into account the water potential values of the Golden Reinders individuals, mean values of -8 bar was measured for the individuals protected by the hail net, which in all cases were higher than the without hail net, except for one sample. Unprotected individuals produce an average value of about -11 bar, there was a significant difference between the water potential values of the protected and non-protected stocks $(p=0.030)$. The effect of the hail net foliage on the water potential of both varieties is positive at each measurement time, justifying the moderation of the effect of the use of hail net due to changes in stress due to water scarcity and high temperatures. It can also be stated that the water potential of the plants decreased continuously during the vegetation period which can be explained by the prolonged high temperature and the precipitation-free period besides the phenological changes (Figure 5).

Figure 5: Golden Reinders water potential values

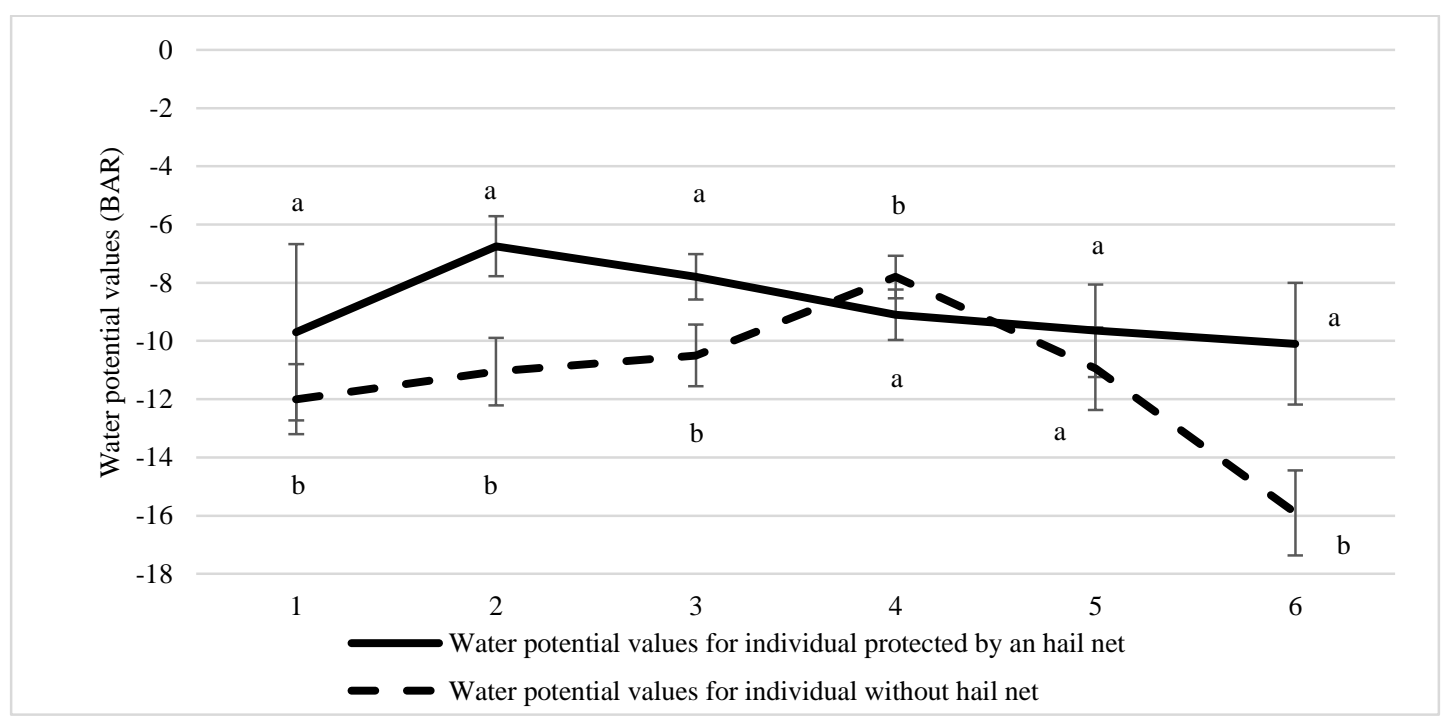

There is no statistical difference between populations marked with the same letter as index character 


\section{CONCLUSIONS}

On the basis of the water potential values of both species it can be observed that higher values were obtained for the individuals protected by the hail net. Higher values gave better water potential, so the positive effects of ice protection nets prevailed in the study, since in both species 10 times better results were obtained from the samples protected by ice nets. Positive effects of the use of hail net were observed for water potential measurement values, temperature and humidity values for both species. Furthermore, there is lack of available Hungarian references for measuring the water potential of apple orchards, so these are the preliminary results of the Hungarian investigation.

\section{ACKNOWLEDGEMENTS}

The research underpinning the study was supported by the Institutional Excellence Program for Higher Education, published by the Ministry of Innovation and Technology, under NKFIH-1150-6/2019, in the framework of the $4^{\text {th }}$ thematic program of the University of Debrecen.

\section{REFERENCES}

Boyer, J.S. (1967): Leaf water potentials measured with a pressure chamber. Plant Physiology 42: 133-137.

Bratek, Z.-Fodor, F.-Király, I.-Nyitrai，P.-Parádi, I.-Rácz, I.Rudnóy, Sz.-Solti, Á.-Szigeti, Z.-Tamás, L. (2013): A növényi anyagcsere élettana. Eötvös Loránd Tudományegyetem

Fulton, A.-Grant, J.-Buchner, R.-Conell, J. (2014): Using the Pressure Chamber for Irrigation Management in Walnut, Almond and Prune (ANR Publication 8503 University of California) 1-27.

Gonda, I--Apáti, F. (2013): Versenyképes almatermesztés 5-317.

Gonda, I.-Csihon, Á. (2018): A gyümölcstermesztés alapjai 5-199.

Kadosa, G. (2010): $\mathrm{Mi}$ is az a jégháló? 1 p https://www.agrarszektor.hu/gepek/mi-is-az-a-jeghalo.112.html

Kállay, T. (2014): Gyümölcsösök termöhelye 5-248.

Klein, T. (2014): The variability of stomatal sensitivity to leaf water potential across tree species indicates a continuum between isohydric and anisohydric behaviours. Funct Ecol 28:13131320.

Lakatos, L.-Gonda, I.-Soltész, M.-Szabó, Z.-Szél, J.-Nyéki, J. (2011): Effects of excessive weather on the micro-climate of apple plantations under the hail protection nets. International Journal of Horticultural Science 2011, 17 (4-5): 81-85.

McDowell, N.G.-Pockman, W.T.-Allen, C.D. (2008): Mechanisms of plant survival and mortality during drought: why do some plants survive while others succumb to drought? New Phytol 178:719-739.

Mendiburu, F. (2019): agricolae: Statistical Procedures for Agricultural Research. $\mathrm{R}$ package version 1.3-0. https://CRAN.R-project.org/package=agricolae
Nagy, A. (2014): Spektrális vizsgálati módszerek aszály és stressz monitorozásában, öntözéstervezésben. Debreceni Egyetem, Debrecen. TÁMOP 4.2.4.A/2-11-1-20120001. 5-27.

Nagy, A.-Fórián, T.-Tamás, J.-Szabó, Z.-Soltész, M. (2011): Monitoring of water regime in an apple orchard, International Journal of Horticultural Science, ISSN: 1585-0404, Vol:17 1-2 29-32.

Ördög, V.-Molnár, Z. (2011): Növényélettan 1-78.

Petesné, H.A. (2008): A legegészségesebb gyümölcseink az almatermésủek, környezeti igényeik, termesztéstechnológiájuk, betakarításuk és tárolásuk 5-53.. http://kepzesevolucioja.hu/dmdocuments/4ap/20_2228_003_10 1231.pdf

Scholander, P.F.-Hammel, H.T.-Bradstreet, E.D.-Hemmingsen, E.A. (1965): Sap pressure in vascular plants. Science 148: 339346.

Steppe, K. (2018): The potential of the tree water potential. Tree Physiology 38, 937-940 doi:10.1093/treephys/tpy064

Szabó, V. (2016.): Agrártudományi Közlemények, 2016/68. Economics of hail protection net installation in super intensive apple orchards 5-35.

Teszlák, P. (2008): A szárazságstressz ökofiziológiai hatásainak összehasonlító elemzése különböző borszőlőfajtáknál (Vitis vinifera L.) Doktori értekezés 1-141. 
